\title{
Ivana Brač i Ana Ostroški Anić (ur.), Svijet od riječi, Leksikografski i terminološki ogledi, Institut za hrvatski jezik i jezikoslovlje, Zagreb, 2020.
}

Naslov knjige Svijet od riječi: leksikografski i terminološki ogledi, objavljene 2020. godine u izdanju Instituta za hrvatski jezik i jezikoslovlje, otkriva glavna lingvistička stremljenja Maje Bratanić, iznimne znanstvenice i profesorice kojoj je knjiga posvećena povodom 70 . rođendana. Riječi u odnosu na svijet, odnosno »terminološkim jezikom « nazivi u strukovnome diskursu, u središtu su proučavanja Maje Bratanić, a leksikografija i terminologija glavne lingvističke discipline među različitim znanstvenim interesima koji su je okupirali. U zborniku je na 412 stranica okupljeno 20 radova 27 autora iz područja leksikografije, leksikologije, terminologije i terminografije, uz predgovor, sažetke radova na engleskome jeziku te atraktivnu naslovnicu autora Damira Gamulina. Tomu su dodane iscrpna biografija i bibliografija Maje Bratanić iz koje valja izdvojiti iznimnu znanstvenu predanost i bogato predavačko iskustvo.

Zbornik Svijet od riječi: terminološki i leksikografski ogledi okuplja radove na hrvatskome i engleskome jeziku podijeljene u četiri tematske cjeline prema područjima kojima se Maja Bratanić najviše bavila. U prvoj cjelini leksikološke i leksikografske teme prikazane su u radovima Kristine Štrkalj Despot i Ane Ostroški Anić, Mirjane Borucinsky i Borisa Pritcharda, Masline Ljubičić, Anje Nikolić-Hoyt, Matee Birtić te Ivane Brač i Siniše Runjaića. Druga je cjelina posvećena terminološkim radovima Rite Temmerman, Marine Bergovec, Delyth Prys, Tegau Andrews i Gruffudda Prysa, Brune Nahoda, Lane Hudeček i Milice Mihaljević, Maje Matijević te Tomislave Bošnjak Botica. Terminologija u pravu Europske unije tema je treće cjeline, a autori su radova Martina Bajčić, Maja Lončar te Larisa Grčić Simeunović i Luka Planinić. Naposljetku, u četvrtoj tematskoj cjelini prikazane su terminološke baze i baze znanja u radovima Mojce Pecman, Ágote Fóris i Eszter B. Papp, Sandre Cuadrado i Ane Ostroški Anić.

U prvome radu, naslovljenome Pregled razvoja hrvatske e-leksikografije, Kristina Štrkalj Despot i Ana Ostroški Anić opisuju razvoj e-leksikografije u Hrvatskoj od samih početaka u kojima je sudjelovala Maja Bratanić do razvoja terminološke baze Struna, dakle od prvih korpusno utemeljenih rječnika do izvorno digitalnoga rječnika Mrežnika. Među projektima Maje Bratanić u ovom se radu izdvajaju Hrvatski čestotni rječnik, koji je napisala u suautorstvu s Milanom Mogušom i Markom Tadićem, višejezični leksikografski projekt COBUILD Johna Sinclaira, u kojemu je Bratanić bila voditeljica za hrvatski jezik i koji je iznimno važan za razvoj suvremene hrvatske leksikografije, te terminološka baza hrvatskoga strukovnog nazivlja Struna Instituta za hrvatski jezik i jezikoslovlje, čija je bila voditeljica od 2009. do kraja 2015. godine. 
Drugi je rad Leksikografska studija leksičkoga para marime - maritime u engleskome i njihovih istovrijednica u hrvatskome jeziku u kojemu Mirjana Borucinsky i Boris Pritchard iscrpno analiziraju značenje i uporabu pridjeva marine i maritime u engleskome jeziku, njihova razlikovna obilježja i njihove hrvatske istovrijednice morski i pomorski te pritom definiraju u kojim sintaktičko-semantičkim uvjetima ti pridjevi nisu zamjenjivi.

U radu O refleksima germanskoga etimona bank- $u$ hrvatskim govorima Maslina Ljubičić prikazuje upotrebu toga etimona u hrvatskim govorima, u koje je ušao iz njemačkoga i talijanskoga jezika, a u novije vrijeme aktualni su i anglizmi čija se nova značenja preuzimaju izravno.

Slijedi rad Ludička komponenta imenovanja u kojemu Anja Nikolić-Hoyt na primjeru dijelova tijela istražuje ludičku komponentu imenovanja, koja se kao odraz zaigranosti ljudskoga uma leksikalizira u pojmovima iz općega leksika, ali i u specijaliziranome znanju.

Matea Birtić autorica je rada Usporedba semantičkoga opisa u e-Glavi sa semantičkim opisima u drugim mrežnim valencijskim rječnicima koji se ponajprije bavi semantičkim opisom dopuna toga mrežnog valencijskog rječnika hrvatskih glagola osmišljena u Institutu za hrvatski jezik i jezikoslovlje. Također se u radu taj resurs, koji je utemeljen na njemačkoj valencijskoj tradiciji, uspoređuje s trima istaknutim mrežnim resursima koja obrađuju valencijska svojstva leksičkih jedinica - FrameNetom, FrameBankom i PDEV-om.

Glagole u hrvatskome strukovnom nazivlju proučavaju Ivana Brač i Siniša Runjaić $u$ istoimenome radu ističući da se u okviru suvremenih terminoloških teorija pojačalo zanimanje za istraživanje te vrste riječi u kontekstu strukovnih jezika. Autori ponajprije daju pregled dosadašnjih istraživanja te potom nastoje odgovoriti na pitanje koji se glagoli i na temelju kojih kriterija u terminološkoj bazi Struna mogu smatrati nazivima.

Rita Temmermman u radu Terminology across languages: Researching neologisms and terminological variation in multilingual settings istražuje neologizme i terminološku varijaciju koji stvaraju velik izazov prevoditeljima. Neologizmi i mogućnost njihova prevođenja proučavani su u mnogim suvremenim terminološkim studijama, a pritom su vrijedan alat paralelni korpusi prijevodnih tekstova.

Tema terminološke varijacije nastavlja se u radu Prijedlog klasifikacije hrvatskih terminoloških varijanata u kojemu je Marina Bergovec provela jezičnu i pojmovnu analizu naziva na primjeru hrvatskoga medicinskoga jezika (poddomena koronarne bolesti srca) vodeći računa o izražajnim posebnostima hrvatskoga jezika.

U radu Term formation in Welsh: Problems and solutions Delyth Prys, Tegau Andrews i Gruffudd Prys opisuju stvaranje naziva i njihovu standardizaciju na primjeru velškoga jezika. Navode se i čimbenici koji su utjecali na metodu stvaranja naziva u velškomejeziku, kao što su morfosintaktičke značajke i sociolingvistička sastavnica.

Na primjeru komparativne analize 300 pridjeva iz Strune Bruno Nahod u radu O nazivnosti pridjeva: komparativna analiza pridjeva u Struni i rječnicima općega jezika 
nastoji pokazati da tradicionalni terminološki pristup ne doprinosi kvaliteti obrade strukovnoga jezika u suvremenim terminološkim bazama. Nahod predlaže način obrade u slučajevima kad pridjevi nisu dovoljno značenjski prozirni prosječnomu korisniku.

Slijedi rad Holonimija i meronimija u Jeni Lane Hudeček i Milice Mihaljević. U prvome dijelu rada opisan je projekt Hrvatsko jezikoslovno nazivlje - Jena, zatim se analizira obrada semantičkih odnosa u Jeni (sinonimija, antonimija, hiperonimijahiponimija), a poseban je naglasak stavljen na holonimni-meronimni odnos, kojije iznimno važan u tome projektu.

Jezikoslovno se nazivlje obrađuje i u radu koji je posvećen opisu prvoga susreta $s$ terminološkim radom i terminografskom metodologijom kakva se primjenjuje u bazi Struna. Maja Matijević opisuje prvi susret s terminologijom u istoimenome radu, gdje iz perspektive obrađivača na projektu Hrvatsko jezikoslovno nazivlje Jena iznosi izazove pri odabiru i obradi naziva iz područja glotodidaktike, odnosno ovladavanja hrvatskim kao inim jezikom (sinonimi, višeznačni nazivi, konflikt sa strukom ili normom).

U radu Jezično savjetništvo u terminologiji Tomislava Bošnjak Botica iz perspektive jezičnoga savjetnika na primjerima iz hrvatske terminološke baze Struna opisuje teškoće odabira preporučenoga naziva, posebice u slučaju ustaljenoga internacionalizma i novotvorenice. Bošnjak Botica navodi da je u hrvatskome jeziku načelo da domaći naziv ima prednost pred stranim veoma naglašeno, govori i o čimbenicima koji utječu na izbor preporučenoga naziva te o jezičnom purizmu u nazivlju.

Nakon terminoloških radova koji obrađuju neke od tipičnih terminoloških tema, sljedeća tematska cjelina počinje radom Martine Bajčić koja tematizira terminologiju u pravu EU-a s obzirom na višejezičnost dokumenata i utjecaj engleskoga jezika kao lingua franca. Autorica kritički propituje neutralnost nazivlja EU-a, što se preslikava u pretpostavljenu semantičku neutralnost pravnih pojmova EU-a.

Slijedi tematski povezan rad Maje Lončar Terminološka dosljednost u Ugovorima EU- $a$ u kojemu se s pomoću paralelnoga korpusa analizira nazivlje koje se upotrebljava u hrvatskoj i engleskoj inačici Ugovora EU-a. Dobiveni rezultati razvrstani su u skupine s obzirom na odnos broja pojmova i broja naziva na hrvatskome i engleskome jeziku koji te pojmove označuju.

Larisa Grčić Simeunovići Luka Planinić zatvaraju treću tematsku cjelinu radom Prilog usklađivanju hrvatskih naziva za europske pojmove u bazi IATE u kojem opisuju određene probleme s kojima su se susreli pri obradi hrvatskoga strukovnog nazivlja u toj višejezičnoj bazi. Autori su izradili korpus relevantnih pravnih tekstova europskih institucija za područje kulture i u njemu analizirali četrdesetak pojmova, pri čemu su obratili pozornost na teškoće određivanja pojmovnih granica, a i nastojali su predložiti hrvatske istovrijednice.

U radu 10th anniversary of the ARTES terminological and phraseological database: On the advantages for combining disciplinary with transdisciplinary language resources Mojca Pecman predstavlja inovativnu francusku terminološku i frazeološku bazu 
ARTES te vrijedne promjene koje su provedene na toj deset godina staroj bazi. U radu je definirana uloga projekta ARTES i koji su ciljevi postignuti novim dizajnom baze.

A preliminary study for the information structure of the terminology entry in the Hungarian (national) terminology database rad je Agote Foris i Ester B. Papp u kojemu opisuju potrebne predradnje za izgradnju mađarske nacionalne terminološke baze, strukturu postojeće baze, kategorije podataka i iskustva korisnika. Također se mađarska baza uspoređuje s drugim nacionalnim terminološkim bazama.

Rad Sandre Cuadrado Terminology and communication in the digital era: The humanization of a new discourse posljednji je rad na engleskom jeziku, u kojemu je autorica na primjeru katalonskoga iskustva prikazala proces stvaranja nazivlja. Istaknuto je da se komunikacijski izazovi u terminologiji prevladavaju suvremenim sredstvima - sukreiranjem nazivlja s korisnicima ili interaktivnim alatima koji dopuštaju korisnicima validaciju njihova terminološkog rada.

Zbornik zaokružuje rad Ane Ostroški Anić Hrvatsko zrakoplovno nazivlje od leksikografije do terminologije u kojemu su prikazane različite mogućnosti obrade nazivlja na primjeru hrvatskoga zrakoplovnog nazivlja. Budući da je zrakoplovstvo bilo glavno područje istraživanja strukovnih jezika Maje Bratanić, Ostroški Anić za kraj je opisala obradu hrvatskoga zrakoplovnog nazivlja u trima izvorima: glosaru Aviation English Terms and Collocations, terminološkoj bazi Struna i leksičkoj bazi AirFrame, ističući njihove prednosti i moguće nedostatke.

Svijet od riječi vrijedna je posveta leksikografkinji, terminologinji, profesorici i mentorici Maji Bratanić kojom su joj urednice Ivana Brač i Ana Ostroški Anić te autori dvadeset radova željeli zahvaliti na njezinu neizmjernom znanstvenom i stručnom doprinosu, kolegijalnosti i brižnom mentorstvu te pokazati koliko je utjecala na oblikovanje i usmjeravanje njihova rada. Maja Bratanić neosporno je obogatila hrvatsko jezikoslovlje, posebice leksikografiju i terminologiju, te je zbornik u povodu njezina 70. rođendana logičan dar kojim se znanstvena zajednica odužuje ovoj iznimnoj znanstvenici. Kako su urednice istaknule u predgovoru knjizi, Maja Bratanić bila je dijelom nekih od najvažnijih projekata u povijesti hrvatske leksikografije, no njezina se najveća profesionalna zasluga ogleda u pridruživanju hrvatske terminologije suvremenim europskim i svjetskim tokovima. U tom smislu ovaj svečarski zbornik nije samo kompilacija radova kojima kolege i prijatelji odaju čast profesorici Bratanić pisanjem rada o nekoj od »njezinih“ tema, nego je knjiga tematski zaokruženo djelo u kojem se radovima o aktualnim leksikografskim, a napose terminološkim temama, daje kratak pregled dosadašnjih istraživanja, ali i poticaj za buduća istraživanja. U hrvatskoj jezikoslovnoj literaturi i dalje postoji potreba za sveobuhvatnijim leksikografskim i terminološkim radovima koji bi dopunili pedagošku literaturu iz tih područja. Stoga ovaj zbornik radova može poslužiti i kao svojevrstan priručnik kojim se nove generacije mladih jezikoslovaca mogu uvesti u područja leksikografije i terminologije i graditi nove svjetove i njihove riječi. 